\title{
ZACHOWANIA ŻYWIENIOWE PIELĘGNIAREK W ŚRODOWISKU PRACY
}

\author{
NURSES' EATING HABITS IN THE WORKPLACE \\ Grażyna Gładysz ${ }^{1}$, Ewa Kobos ${ }^{2}$, Józefa Czarnecka ${ }^{3}$, Jacek Imiela² \\ ${ }^{1}$ Centrum Kompleksowej Rehabilitacji, Konstancin \\ ${ }^{2}$ Zakład Pielęgniarstwa Społecznego \\ Warszawski Uniwersytet Medyczny \\ ${ }^{3}$ Zakład Podstaw Pielęgniarstwa \\ Warszawski Uniwersytet Medyczny
}

DOI: http://dx.doi.org/10.20883/pielpol.2016.3

\section{STRESZCZENIE}

Wstęp. Zachowania żywieniowe to postawy i sposoby postępowania człowieka, które w bezpośredni sposób powiązane są z zaspokajaniem potrzeb żywieniowych. Wśród czynników warunkujących zachowania żywieniowe wskazuje się rodzaj wykonywanej pracy oraz zawód.

Cel. Głównym celem badań była analiza zachowań żywieniowych pielęgniarek w środowisku pracy.

Materiał i metody. W badaniu wzięło udział 140 pielęgniarek. Dobór próby do badań był celowy i polegał na świadomym wybraniu terenu badań, jakim był szpital, oraz osób mających minimum roczny staż pracy w zawodzie. W celu zebrania danych wykorzystano autorski kwestionariusz ankiety. Analizę danych przeprowadzono z użyciem programów SPSS Statistics i Statistica.

Wyniki. W badanej grupie pielęgniarki z oddziałów zachowawczych spożywały większą liczbę posiłków niż te z oddziałów operacyjnych. Pielęgniarki pracujące w systemie jednozmianowym częściej spożywały 3 średnie posiłki dziennie, pracujące w systemie równoważnym - 4-5 mniejszych. Jak wynika z badań, pielęgniarki pracujące na nocnej zmianie częściej spożywają posiłki niż pielęgniarki niepracujące w tym czasie. Badane rzadko wypijały w pracy: soki owocowe i warzywne, napoje mleczne, napoje gazowane i niegazowane. Przekąskami rzadko spożywanymi w pracy były: owoce, serki/jogurty, słodycze, chipsy, orzeszki. Dania typu instant częściej były spożywane w oddziałach zabiegowych.

Wnioski. Na zachowania żywieniowe pielęgniarek w środowisku pracy nie ma wpływu dostępność do stołówki/baru w miejscu pracy. Zmienne: staż pracy, system pracy i rodzaj oddziału mają wpływ na prezentowane przez pielęgniarki zachowania żywieniowe w pracy.

SŁOWA KLUCZOWE: pielęgniarka, zachowania żywieniowe, środowisko pracy.

\section{Wprowadzenie}

Zachowania żywieniowe to postawy i sposoby postępowania człowieka, które w bezpośredni sposób powiązane są z zaspokajaniem potrzeb żywieniowych

\begin{abstract}
Introduction. Eating habits are human behaviours and attitudes, directly connected with fulfilling nutritional needs. Some indicated determinants of eating behaviours are a type of work and occupation.

Aim. The main aim of the study was analysis of nurses' eating habits in the workplace.

Material and methods. 140 nurses took part in the research. Sampling was chosen intentionally and included a conscious selection of the research area and staff having at least one year's experience in the job. A method of a diagnostic pool by means of the author's own questionnaire was used to collect the data, later analysed using the SPSS Statisctics and Statistica programme. Results. Among the study group, nurses from non-invasive treatment wards consumed a higher number of meals when compared to the surgical ward nurses. Nurses working on a one-shift pattern consumed 3 medium meals a day, and those with flexible working hours - 4-5 smaller meals. Research showed that nurses working during the night shift reached out for food more frequently than those working other shifts. Respondents rarely drank fruit and vegetable juices, milk, sparkling and still drinks. Among snacks that were rarely chosen at work were: fruit, yoghurts / dairy products, sweets, crisps, nuts. Instant food was among the most often consumed products at medical treatment wards.

Conclusions. Eating habits of nurses are not influenced by the access to the canteen / restaurant at work. Variables such as the length of employment, shift pattern and type of a ward show not to have impact on nurses' eating habits at work.
\end{abstract}

KEYWORDS: nurse, eating habits, workplace.

[1]. Postępowanie człowieka w sferze żywieniowej jest zależne od wielu czynników, m.in. tych związanych z rodzajem wykonywanej pracy (np. praca zmianowa oraz nocna) oraz zawodem [2]. Barierą lub udogodnie- 
niem we wprowadzaniu zmian żywieniowych może być środowisko fizyczne - infrastruktura usługowa, miejsce spożycia posiłków, dostępność żywności - które może istotnie wpłynąć na ilość i jakość spożytego pożywienia [3]. Do zadań szpitala należą działania zarówno na rzecz poprawy warunków pracy, jak i promowania zdrowego żywienia wśród personelu [4], co może przyczynić się do wzrostu satysfakcji personelu z pracy, wzrostu skuteczności i wydajności pracy szpitala oraz poprawy jakości udzielanych świadczeń [5].

\section{Cel pracy}

Celem prezentowanych badań jest analiza zachowań żywieniowych pielęgniarek w środowisku pracy. Sformułowano następujące pytanie badawcze: czy zmienne opisujące charakter i warunki pracy - staż pracy, system pracy, rodzaj oddziału, dostępność do stołówki/baru w miejscu pracy - mają znaczenie w prezentowanych przez pielęgniarki zachowaniach żywieniowych w pracy?

\section{Materiał i metody}

Grupę badaną stanowiło 140 pielęgniarek pracujących w oddziałach szpitalnych nie krócej niż rok. Do zebrania materiału badawczego wykorzystano kwestionariusz ankiety własnej konstrukcji. Przed przystąpieniem do badań właściwych rozdano 20 ankiet pilotażowych w celu weryfikacji narzędzia badawczego i zakresu badań. Analizy statystyczne wykonano, wykorzystując program SPSS. Wyniki przedstawiono za pomocą frakcji procentowych, statystyk opisowych oraz metod statystycznych.

W badaniu wzięły udział respondentki w wieku 23-56 lat - w wieku 23-29 lat było 66 (47\%) badanych, w wieku 20-39 lat - 24 (17\%) badanych, 40-49 lat $38(27 \%)$ badanych oraz > 50 lat $-12(9 \%)$ badanych. Średnia wieku wynosiła 34,3 roku (SD = 10). W badanej grupie wykształcenie wyższe miało 114 (81\%) ankietowanych, średnie zawodowe - 29 (19\%). Badane osoby pracowały w zawodzie od roku do 35 lat, średni staż pracy wyniósł 12,8 roku (SD = 11). W oddziałach zabiegowych pracowało $85(61 \%)$ respondentek, w oddziałach zachowawczych - 55 (39\%). Spośród ankietowanych 109 (78\%) pracowało w systemie pracy równoważnym, czyli praca odbywała się w ciągu dnia i w nocy po 12 godzin.

\section{Wyniki}

Analizując materiał badawczy, uzyskano następujące wyniki. Najwięcej ankietowanych - 58 (41\%) - najczęściej spożywało 3 średnie posiłki, 33 (24\%) badane - 4-5 mniejszych. Pielęgniarki pracujące w systemie równoważnym i 12-godzinnym w ciągu dnia spożywają w pracy więcej posiłków niż pracujące w systemie jednozmianowym. Nie wykazano zależności istotnie statystycznej $(p=0,327)$ między systemem pracy a liczbą posiłków spożywanych w pracy. Dane prezentuje tabela 1.

Tabela 1. Liczba posiłków spożywanych w pracy a system pracy Table 1. Number of meals consumed at work and type of the working pattern

\begin{tabular}{|c|c|c|c|c|c|}
\hline \multirow{2}{*}{\multicolumn{2}{|c|}{ Zmienne/Factors }} & \multicolumn{4}{|c|}{$\begin{array}{l}\text { Liczba spożywanych posiłków w pracy/ } \\
\text { Number of meals consumed at work }\end{array}$} \\
\hline & & $\begin{array}{c}\text { 4-5 mniejszych } \\
\text { positków/ } \\
4-5 \text { smaller } \\
\text { meals }\end{array}$ & $\begin{array}{c}3 \text { średnie } \\
\text { posiłki/ } \\
3 \text { medium } \\
\text { meals }\end{array}$ & $\begin{array}{c}\text { 1-2 duże } \\
\text { posiłki/ } \\
1-2 \text { large } \\
\text { meals }\end{array}$ & $\begin{array}{l}\text { Inna/ } \\
\text { Other }\end{array}$ \\
\hline $\begin{array}{r}\text { System prac } \\
\text { Type of working }\end{array}$ & pattern & \multicolumn{4}{|c|}{$\chi^{2}=10,29(\mathrm{df}=9) ; p=0,327$} \\
\hline $\begin{array}{l}\text { Jedna zmiana } \\
8 \text { godzin/ } \\
\text { One shift } \\
8 \text { hours }\end{array}$ & $\mathrm{N}(\%)$ & $0(0)$ & $8(57)$ & $4(29)$ & 2 (14) \\
\hline $\begin{array}{l}\text { Równoważny/ } \\
\text { Flexible working } \\
\text { time }\end{array}$ & $N(\%)$ & $27(25)$ & $44(40)$ & $32(30)$ & $6(5)$ \\
\hline $\begin{array}{l}12 \text { godzin } \\
\text { w ciagu dnia/ } \\
12 \text { hours a day }\end{array}$ & $N(\%)$ & $4(36)$ & $5(46)$ & $2(18)$ & $0(0)$ \\
\hline Inny/Other & $\mathrm{N}(\%)$ & 2 (33) & 1 (17) & $3(50)$ & $0(0)$ \\
\hline
\end{tabular}

p - prawdopodobieństwo testowe/probability value,

$\chi^{2}$ - wartość testu chi-kwadrat/value of the chi-square test

Źródło: opracowanie własne

Source: author's own analysis

W badanej grupie 28 (44\%) pielęgniarek spożywających w pracy 1-2 duże posiłki miało do 5 lat stażu pracy w zawodzie, 3 (50\%) miały staż pracy od 6 do 10 lat, kolejne 10 (32\%) - 11-20 lat. Pielęgniarki powyżej 20 lat stażu pracy w ogóle nie jadały 1-2 posiłków, ale 23 (59\%) z nich spożywały w pracy 3 średnie posiłki, a 14 (36\%) -4-5 mniejszych. Stwierdzono zależność istotnie statystyczną $(p<0,001)$ między stażem pracy a liczbą spożywanych posiłków w pracy. Dane prezentuje tabela 2. 
Tabela 2. Liczba posiłków spożywanych w pracy a staż pracy Table 2. Number of meals consumed at work and work experience

\begin{tabular}{|c|c|c|c|c|c|}
\hline \multirow{2}{*}{\multicolumn{2}{|c|}{ Zmienne/Factors }} & \multicolumn{4}{|c|}{$\begin{array}{l}\text { Liczba spożywanych posiłków w pracy/ } \\
\text { Number of meals consumed at work }\end{array}$} \\
\hline & & $\begin{array}{l}\text { 4-5 mniej- } \\
\text { szych } \\
\text { posiłków/ } \\
4-5 \text { smal- } \\
\text { ler meals }\end{array}$ & $\begin{array}{c}3 \text { średnie } \\
\text { posiłki/ } \\
3 \text { medium } \\
\text { meals }\end{array}$ & $\begin{array}{c}1-2 \\
\text { duże } \\
\text { posiłki/ } \\
1-2 \\
\text { large } \\
\text { meals }\end{array}$ & $\begin{array}{l}\text { Inna/ } \\
\text { Other }\end{array}$ \\
\hline $\begin{array}{c}\text { Staż pracy/ } \\
\text { Work experience }\end{array}$ & & \multicolumn{4}{|c|}{$\chi^{2}=26,88(d f=9) ; p<0,001$} \\
\hline $0-5$ lat/0-5 years & $\mathrm{N}(\%)$ & $12(19)$ & $19(30)$ & $28(44)$ & $5(7)$ \\
\hline $6-10$ lat/6-10 years & $\mathrm{N}(\%)$ & $1(17)$ & $2(33)$ & $3(50)$ & $0(0)$ \\
\hline $11-20$ lat/11-20 years & $\mathrm{N}(\%)$ & $6(19)$ & $14(45)$ & $10(32)$ & $1(4)$ \\
\hline$>20$ lat/> 20 years & $\mathrm{N}(\%)$ & $14(36)$ & $23(59)$ & $0(0)$ & $2(5)$ \\
\hline
\end{tabular}

p - prawdopodobieństwo testowe/probability value,

$\chi^{2}$ - wartość testu chi-kwadrat/value of the chi-square test

Źródło: opracowanie własne

Source: author's own analysis

Z analizy porównawczej wynika, że liczba spożywanych w pracy posiłków w ciągu dnia zależy od rodzaju oddziału $(p=0,035)$. W oddziałach zachowawczych pielęgniarki spożywały większą liczbę posiłków niż w oddziałach zabiegowych, co może wynikać ze zróżnicowanego charakteru pracy na tych oddziałach. Liczba posiłków spożywanych przez pielęgniarki mające dostęp do stołówki/baru w miejscu pracy jest porównywalna z liczbą posiłków spożywanych przez pielęgniarki, które nie mają w pracy stołówki/baru $(38 \%$ vs $42 \%-3$ średnie posiłki). $Z$ badań wynika, że pielęgniarki nie spożywają regularnie obiadów w pracy. System pracy różnicuje regularność spożycia podwieczorku $(p=0,031)$. W grupach jednorodnych nie wykazano istotnych statystycznie różnic. Są istotnie statystyczne różnice między grupami „inny” i „praca 12-godzinna w ciągu dnia”. Osoby pracujące w systemie pracy „inny” regularniej spożywały podwieczorek niż osoby pracujące w systemie pracy 12 godzin w ciągu dnia. Nie ma istotnych statystycznie różnic $(p=0,165) w$ regularności spożywania kolacji $w$ pracy $w$ zależności od systemu pracy. Są istotnie statystyczne różnice między grupami „praca jednozmianowa 8-godzinna” i „praca 12-godzinna w ciągu dnia". Osoby pracujące w systemie pracy jednozmianowej regularniej spożywały ko- lację niż osoby pracujące w systemie pracy 12 godzin w ciągu dnia. Dane prezentuje tabela 3.

Tabela 3. Regularność spożycia posiłków w pracy a system pracy Table 3. Regularity of meal consumption at work and the type of the working pattern

\begin{tabular}{|c|c|c|c|c|c|}
\hline Zmien & ine/Factors & $\begin{array}{c}\text { Suma } \\
\text { kwadratów/ } \\
\text { The sum } \\
\text { of the } \\
\text { squares }\end{array}$ & df & $\begin{array}{c}\text { Średni } \\
\text { kwadrat/ } \\
\text { Average } \\
\text { square }\end{array}$ & $\begin{array}{c}\text { P } \\
\text { Probabi- } \\
\text { lity } \\
\text { value }\end{array}$ \\
\hline & System pracy/T & pe of the wor & king $p a$ & tern & \\
\hline & $\begin{array}{l}\text { między grupami/ } \\
\text { between groups }\end{array}$ & 0,499 & 3 & 0,166 & 0,568 \\
\hline $\begin{array}{c}\text { Śniadanie/ } \\
\text { Breakfast }\end{array}$ & $\begin{array}{l}\text { wewnątrz grup/ } \\
\text { within groups }\end{array}$ & 27,976 & 114 & 0,245 & \\
\hline & $\begin{array}{l}\text { ogółem/ } \\
\text { total }\end{array}$ & 28,475 & 117 & & \\
\hline Drugie & $\begin{array}{l}\text { między grupami/ } \\
\text { between groups }\end{array}$ & 1,446 & 3 & 0,482 & 0,099 \\
\hline $\begin{array}{l}\text { śniadanie/ } \\
\text { Second }\end{array}$ & $\begin{array}{c}\text { wewnątrz grup/ } \\
\text { within groups }\end{array}$ & 21,054 & 94 & 0,224 & \\
\hline breakfast & $\begin{array}{l}\text { ogółem/ } \\
\text { total }\end{array}$ & 22,500 & 97 & & \\
\hline & $\begin{array}{l}\text { między grupami/ } \\
\text { between groups }\end{array}$ & 0,515 & 3 & 0,172 & 0,568 \\
\hline $\begin{array}{l}\text { Obiad/ } \\
\text { Dinner }\end{array}$ & $\begin{array}{l}\text { wewnątrz grup/ } \\
\text { within groups }\end{array}$ & 31,733 & 125 & 0,254 & \\
\hline & $\begin{array}{l}\text { ogółem/ } \\
\text { total }\end{array}$ & 32,248 & 128 & & \\
\hline & $\begin{array}{l}\text { między grupami/ } \\
\text { between groups }\end{array}$ & 1,685 & 3 & 0,562 & 0,031 \\
\hline $\begin{array}{l}\text { Podwieczorek/ } \\
\text { Aftemoon tea }\end{array}$ & $\begin{array}{l}\text { wewnątrz grup/ } \\
\text { within groups }\end{array}$ & 13,870 & 77 & 0,180 & \\
\hline & $\begin{array}{c}\text { ogółem/ } \\
\text { total }\end{array}$ & 15,556 & 80 & & \\
\hline & $\begin{array}{l}\text { między grupami/ } \\
\text { between groups }\end{array}$ & 1,271 & 3 & 0,424 & 0,165 \\
\hline $\begin{array}{l}\text { Kolacja/ } \\
\text { Supper }\end{array}$ & $\begin{array}{l}\text { wewnątrz grup/ } \\
\text { within groups }\end{array}$ & 23,680 & 97 & 0,244 & \\
\hline & $\begin{array}{l}\text { ogółem/ } \\
\text { total }\end{array}$ & 24,950 & 100 & & \\
\hline
\end{tabular}

Źródło: opracowanie własne

Source: author's own analysis

Różnice istotne statystycznie występują w regularności spożywania posiłków w pracy w zależności od stażu pracy (Tabela 4). Różnice te dotyczą posiłków głównych: śniadania $(p=0,029)$, obiadu $(p=0,036)$ i kolacji $(p=0,000)$. 
Tabela 4. Regularność spożycia posiłków w pracy a staż pracy Table 4. Regularity of meal consumption at work and work experience

\begin{tabular}{|c|c|c|c|c|c|}
\hline $\begin{array}{l}\text { Zmienne/ } \\
\text { Factors }\end{array}$ & $\begin{array}{c}\text { Suma } \\
\text { kwadratów/ } \\
\text { The sum } \\
\text { of the squares }\end{array}$ & df & $\begin{array}{l}\text { Średni } \\
\text { kwa- } \\
\text { drat/ } \\
\text { Average } \\
\text { square }\end{array}$ & $\begin{array}{c}\mathrm{P} \\
\text { Probability } \\
\text { value }\end{array}$ & $\begin{array}{c}\text { Zmienne/ } \\
\text { Factors }\end{array}$ \\
\hline \multicolumn{6}{|c|}{ Staż pracy/Work experience } \\
\hline \multirow{3}{*}{$\begin{array}{l}\text { Śniada- } \\
\text { nie/ } \\
\text { Breakfast }\end{array}$} & $\begin{array}{c}\text { między grupami/ } \\
\text { between groups }\end{array}$ & 2,159 & 3 & 0,720 & 0,029 \\
\hline & $\begin{array}{c}\text { wewnątrz grup/ } \\
\text { within groups }\end{array}$ & 26,315 & 114 & 0,231 & \\
\hline & $\begin{array}{l}\text { ogółem/ } \\
\text { total }\end{array}$ & 28,475 & 117 & & \\
\hline \multirow{3}{*}{$\begin{array}{c}\text { Drugie } \\
\text { śniadanie/ } \\
\text { Second } \\
\text { breakfast }\end{array}$} & $\begin{array}{c}\text { między grupami/ } \\
\text { between groups }\end{array}$ & 0,237 & 3 & 0,079 & 0,801 \\
\hline & $\begin{array}{c}\text { wewnątrz grup/ } \\
\text { within groups }\end{array}$ & 22,263 & 94 & 0,237 & \\
\hline & $\begin{array}{c}\text { ogółem/ } \\
\text { total }\end{array}$ & 22,500 & 97 & & \\
\hline \multirow{3}{*}{$\begin{array}{l}\text { Obiad/ } \\
\text { Dinner }\end{array}$} & $\begin{array}{l}\text { między grupami/ } \\
\text { between groups }\end{array}$ & 2,126 & 3 & 0,709 & 0,036 \\
\hline & $\begin{array}{c}\text { wewnątrz grup/ } \\
\text { within groups }\end{array}$ & 30,122 & 125 & 0,241 & \\
\hline & $\begin{array}{c}\text { ogółem/ } \\
\text { total }\end{array}$ & 32,248 & 128 & & \\
\hline \multirow{3}{*}{$\begin{array}{c}\text { Podwieczorek } \\
\text { Afternoon } \\
\text { tea }\end{array}$} & $\begin{array}{l}\text { między grupami/ } \\
\text { between groups }\end{array}$ & 1,307 & 3 & 0,436 & 0,078 \\
\hline & $\begin{array}{c}\text { wewnątrz grup/ } \\
\text { within groups }\end{array}$ & 14,248 & 77 & 0,185 & \\
\hline & $\begin{array}{c}\text { ogółem/ } \\
\text { total }\end{array}$ & 15,556 & 80 & & \\
\hline \multirow{3}{*}{$\begin{array}{l}\text { Kolacja/ } \\
\text { Supper }\end{array}$} & $\begin{array}{c}\text { między grupami/ } \\
\text { between groups }\end{array}$ & 4,445 & 3 & 1,482 & 0,000 \\
\hline & $\begin{array}{c}\text { wewnątrz grup/ } \\
\text { within groups }\end{array}$ & 20,505 & 97 & 0,211 & \\
\hline & $\begin{array}{c}\text { ogółem/ } \\
\text { total }\end{array}$ & 24,950 & 100 & & \\
\hline
\end{tabular}

Źródło: opracowanie własne

Source: author's own analysis

Wyniki badań nie wykazały różnic $w$ regularności spożywania posiłków w pracy w zależności od rodzaju oddziału $(p>0,05)$. W badanej grupie $60(43 \%)$ pielęgniarek nie potwierdziło faktu spożycia posiłków w porze nocnej w pracy, 86 (62\%) - w porze nocnej w domu. Zimny posiłek nocny w pracy spożywało $66(47 \%)$ respondentek. System pracy istotnie wpływa na spożywanie posiłków w pracy w porze nocnej $(p=0,046)$. Im dłuższy czas pracy w nocy, tym większa liczba spożywanych posiłków. Dane prezentuje tabela 5.

Pielęgniarki ze stażem pracy 6-10 lat częściej spożywały w pracy posiłek w porze nocnej aniżeli respondentki ze stażem pracy 0-5 lat oraz powyżej 20 lat (Tabela 6). Staż pracy ma istotnie znaczenie w spożyciu posiłków w porze nocnej w pracy $(p=0,000)$.
Tabela 5. Spożycie posiłków w porze nocnej w pracy a system pracy Table 5. Meals consumption during the night at work and the type of the working pattern

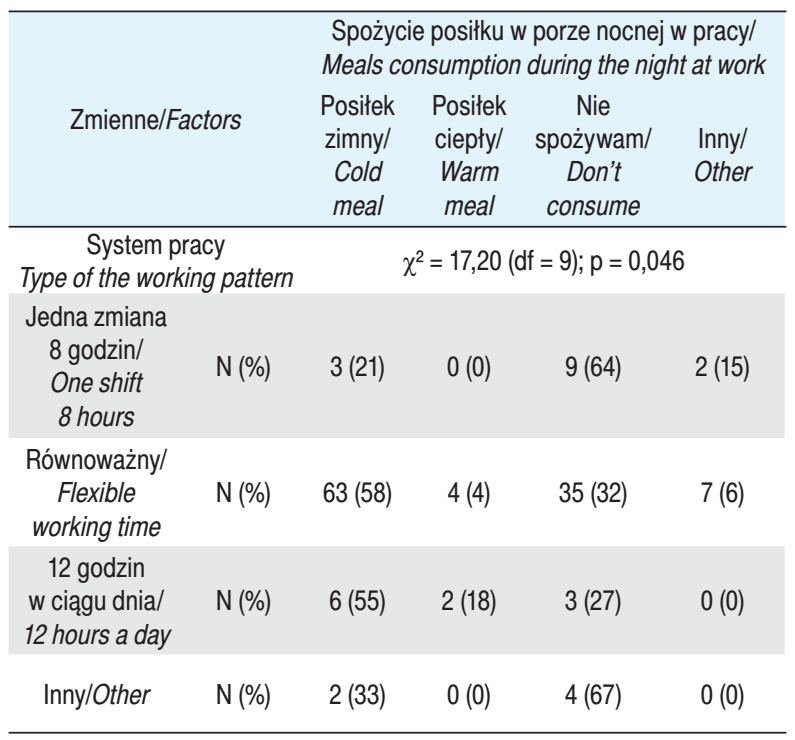

p - prawdopodobieństwo testowe/probability value,

$\chi^{2}$ - wartość testu chi-kwadrat/value of the chi-square test

Źródło: opracowanie własne

Source: author's own analysis

Tabela 6. Spożycie posiłków w porze nocnej w pracy a staż pracy Table 6. Meals consumption during the night at work and work experience

\begin{tabular}{|c|c|c|c|c|c|}
\hline \multicolumn{2}{|l|}{ Zmienne/Factors } & \multicolumn{4}{|c|}{$\begin{array}{l}\text { Spożycie posiłku w porze nocnej w pracy/ } \\
\text { Meals consumption during the night at work }\end{array}$} \\
\hline & & $\begin{array}{c}\text { Posiłek } \\
\text { zimny/ } \\
\text { Cold } \\
\text { meal }\end{array}$ & $\begin{array}{c}\text { Posiłek } \\
\text { ciepły/ } \\
\text { Warm } \\
\text { meal }\end{array}$ & $\begin{array}{c}\text { Nie } \\
\text { spożywam/ } \\
\text { Don't } \\
\text { consume }\end{array}$ & $\begin{array}{l}\text { Inny/ } \\
\text { Other }\end{array}$ \\
\hline Staż pracy/Work expe & ience & \multicolumn{4}{|c|}{$\chi^{2}=39,05(d f=9) ; p=0,000$} \\
\hline $0-5$ lat $/ 0-5$ years & $\mathrm{N}(\%)$ & $37(58)$ & $1(1)$ & $25(40)$ & $1(1)$ \\
\hline $6-10$ lat $/ 6-10$ years & $N(\%)$ & $2(33)$ & $3(50)$ & 1 (17) & $0(0)$ \\
\hline 11-20 lat/11-20 years & $N(\%)$ & $15(52)$ & $0(0)$ & $11(35)$ & $4(13)$ \\
\hline$>20$ lat $/>20$ years & $N(\%)$ & 19 (49) & $2(5)$ & $14(36)$ & $4(10)$ \\
\hline
\end{tabular}

$\mathrm{p}$ - prawdopodobieństwo testowe/probability value,

$\chi^{2}$ - wartość testu chi-kwadrat/value of the chi-square test

Źródło: opracowanie własne

Source: author's own analysis

To, w jakim oddziale pracowały pielęgniarki, nie miało istotnego wpływu na spożycie posiłków w pracy $w$ porze nocnej $(p=0,065)$. Zimny posiłek $w$ nocy spożywały 83 (59\%) pielęgniarki mające $w$ pracy dostęp do stołówki/baru. Posiłek taki nie był w ogóle spożywany przez $53(38 \%)$ ankietowane. Żadna osoba z grupy badanej nie wskazała na spożycie ciepłego posiłku w pracy w porze nocnej. Analizy statystyczne nie potwierdziły istotnego związku między spożyciem posiłku w pracy w porze nocnej a możliwością korzystania ze stołówki/ baru na terenie zakładu pracy $(p=0,260)$. Dane prezentuje tabela 7. 
Tabela 7. Dostępność stołówki/baru w miejscu pracy a liczba spożywanych posiłków, spożycie posiłków w porze nocnej

Table 7. Access to the canteen/restaurant at work and the number of meals consumed, meals consumed at night

\begin{tabular}{|c|c|c|c|c|}
\hline \multirow{2}{*}{$\begin{array}{l}\text { Dostępność } \\
\text { stołówki/ } \\
\text { baru w pracy/ } \\
\text { Access to the } \\
\text { canteen/ } \\
\text { restaurant at } \\
\text { work }\end{array}$} & \multicolumn{4}{|c|}{$\begin{array}{l}\text { Liczba spożywanych posiłków w pracy/ } \\
\text { Number of meals consumed at work }\end{array}$} \\
\hline & $\begin{array}{c}\text { 4-5 mniejszych } \\
\text { posiłków/ } \\
4-5 \text { smaller } \\
\text { meals }\end{array}$ & $\begin{array}{l}3 \text { średnie } \\
\text { posiłki/ } \\
3 \text { medium } \\
\text { meals }\end{array}$ & $\begin{array}{c}1-2 \text { duże } \\
\text { positki/ } \\
1-2 \text { large } \\
\text { meals }\end{array}$ & $\begin{array}{l}\text { Inna/ } \\
\text { Other }\end{array}$ \\
\hline $\mathrm{Nie} / \mathrm{No}$ & $8(20)$ & $15(39)$ & $13(33)$ & $3(8)$ \\
\hline Tak/Yes & $25(25)$ & $43(43)$ & 28 (28) & $5(5)$ \\
\hline \multicolumn{5}{|c|}{$\begin{array}{l}\text { Spożycie posiłku w porze nocnej w pracy/ } \\
\text { Meals consumption during the night at work }\end{array}$} \\
\hline $\begin{array}{c}\text { baru } \\
\text { w pracy/ } \\
\text { Access to the } \\
\text { canteen/ } \\
\text { restaurant at work }\end{array}$ & $\begin{array}{l}\text { Posiłek } \\
\text { zimnyl } \\
\text { Cold } \\
\text { meal }\end{array}$ & $\begin{array}{c}\text { Posiłek } \\
\text { ciepły/ } \\
\text { Warm } \\
\text { meal }\end{array}$ & $\begin{array}{l}\text { Nie spoży- } \\
\text { wam/ } \\
\text { Don't } \\
\text { consume }\end{array}$ & $\begin{array}{l}\text { Inny/ } \\
\text { Other }\end{array}$ \\
\hline $\mathrm{Nie} / \mathrm{No}$ & $23(59)$ & $0(0)$ & $15(38)$ & $1(3)$ \\
\hline Tak/Yes & 51 (51) & $6(6)$ & $36(36)$ & $8(8)$ \\
\hline
\end{tabular}

Źródło: opracowanie własne

Source: author's own analysis

Wyniki badań nie wykazały różnic istotnych statystycznie w spożyciu określonych grup produktów spożywczych (mięsa, nabiału, tłuszczów, owoców, warzyw, pieczywa, kasz, słodyczy) w zależności od rodzaju oddziału oraz systemu pracy $(p>0,05)$. Różnice istotne statystycznie występują w spożyciu warzyw surowych w porównaniu z innymi produktami. Ankietowane jedzą istotnie mniej warzyw surowych niż pozostałych produktów $(p=0,001)$. Występuje istotna różnica w częstotliwości spożywania niektórych produktów w zależności od stażu pracy badanych. Różnice widoczne są w spożyciu pieczywa razowego $(p=0,023)$, oleju i margaryny $(p=0,008)$, smalcu $(p=0,019)$ oraz owoców $(p=0,026)$. Osoby ze stażem pracy $>5-10$ lat spożywają istotnie mniej pieczywa razowego niż osoby z pozostałych dwóch grup wiekowych. Jakkolwiek istnieją różnice między grupami w rozkładzie średnich, to nie ma istotnych zależności między stażem pracy a spożywaniem wskazanych produktów spożywczych. Respondentki ze stażem pracy > 5-10 lat spożywają istotnie mniej tłuszczów roślinnych niż osoby z pozostałych grup oraz mniej smalcu niż osoby ze stażem $>10-20$ lat.

Badane osoby rzadko wypijały w pracy soki owocowe, soki warzywne, napoje gazowane, napoje niegazowane oraz napoje mleczne. Pielęgniarki mające dłuższy staż pracy w zawodzie częściej piły kawę w pracy $(p<0,05)$. Nie wykazano istotnych statystycznie różnic w częstotliwości picia napojów w pracy w zależności od systemu pracy badanych. Pracownice oddziałów zachowawczych częściej piły kawę w pracy niż pracownice oddziałów zabiegowych $(p=0,023)$.

Pielęgniarki rzadko spożywały w pracy przekąski typu: owoce, jogurty/serki, słodycze, chipsy i orzeszki. Analiza korelacji pomiędzy częstością spożywania poszczególnych przekąsek $w$ pracy a stażem pracy respondentek wykazała, że osoby $z$ dłuższym stażem pracy rzadziej spożywały między posiłkami w pracy jogurty/serki $(p<0,05)$. Grupą najczęściej spożywającą przekąski w pracy jest grupa zawodowa ze stażem pracy 6-10 lat. Nie wykazano istotnych statystycznie różnic pomiędzy pracownicami pracującymi w różnych systemach pracy oraz w różnych oddziałach pod względem częstości spożycia przekąsek w pracy. Spośród przekąsek najczęściej spożywane są w pracy kanapki. Z danych wynika, że środowisko pracy nie sprzyja zwiększonej częstotliwości spożycia dań typu: gotowe produkty mrożone, posiłki typu „fast food”, półprodukty oraz wyroby garmażeryjne podczas dyżuru $(p<0,05)$ $w$ porównaniu ze środowiskiem domowym. Nie było różnic w spożyciu dań gotowych pomiędzy osobami, które miały zapewnione posiłki przez pracodawcę oraz dostęp do stołówki/baru w miejscu pracy, a tymi osoba$m i$, którym tego nie zapewniono $(p \geqslant 0,05)$. Dane prezentuje tabela 8.

Tabela 8. Średnia częstotliwość spożycia poszczególnych dań w pracy a dostępność stołówki/baru na terenie zakładu pracy Table 8. Average frequency of meals consumed at work and the access to the canteen/restaurant at work

\begin{tabular}{|c|c|c|c|c|}
\hline $\begin{array}{l}\text { Rodzaj dania/ } \\
\text { Type of meall }\end{array}$ & $\begin{array}{c}\text { Dostępność } \\
\text { stołówki/baru/ } \\
\text { Availability of } \\
\text { the canteen/ } \\
\text { restaurant }\end{array}$ & $\begin{array}{l}\text { Średnia/ } \\
\text { Mean }\end{array}$ & $\begin{array}{c}\text { SD } \\
\text { Standard } \\
\text { deviation }\end{array}$ & $\begin{array}{l}\text { P } \\
\text { Probabi- } \\
\text { lity } \\
\text { value }\end{array}$ \\
\hline \multirow{2}{*}{$\begin{array}{l}\text { Dania typu instant/ } \\
\text { Instant food }\end{array}$} & $\mathrm{Nie} / \mathrm{No}$ & 1,85 & 0,99 & \multirow{2}{*}{0,664} \\
\hline & Tak/Yes & 1,79 & 1,01 & \\
\hline \multirow{2}{*}{$\begin{array}{l}\text { Gotowe produkty pakowane } \\
\text { próżniowo/ } \\
\text { Ready-made products } \\
\text { vacuum sealed }\end{array}$} & $\mathrm{Nie} / \mathrm{No}$ & 1,82 & 1,00 & \multirow{2}{*}{0,665} \\
\hline & Tak/Yes & 1,76 & 1,01 & \\
\hline \multirow{2}{*}{$\begin{array}{l}\text { Gotowe produkty mrożone/ } \\
\text { Ready-made frozen products }\end{array}$} & Nie/No & 1,33 & 0,66 & \multirow{2}{*}{0,066} \\
\hline & Tak/Yes & 1,62 & 0,86 & \\
\hline \multirow{2}{*}{$\begin{array}{l}\text { Produkty typu „fast food”/ } \\
\text { Fast food products }\end{array}$} & Nie/No & 1,62 & 0,75 & \multirow{2}{*}{0,492} \\
\hline & Tak/Yes & 1,52 & 0,72 & \\
\hline \multirow{2}{*}{$\begin{array}{l}\text { Półprodukty/ } \\
\text { Processed food }\end{array}$} & Nie/No & 1,49 & 0,72 & \multirow{2}{*}{0,322} \\
\hline & Tak/Yes & 1,66 & 0,86 & \\
\hline \multirow{2}{*}{$\begin{array}{c}\text { Dania zamawiane do domu/ } \\
\text { do pracy/ } \\
\text { Takeaway food delivered to } \\
\text { home/work }\end{array}$} & Nie/No & 2,00 & 1,41 & \multirow{2}{*}{0,728} \\
\hline & Tak/Yes & 1,70 & 0,67 & \\
\hline \multirow{2}{*}{$\begin{array}{l}\text { Konserwy/ } \\
\text { Preserved food }\end{array}$} & Nie/No & 1,95 & 0,92 & \multirow{2}{*}{0,142} \\
\hline & Tak/Yes & 1,73 & 0,94 & \\
\hline \multirow{2}{*}{$\begin{array}{l}\text { Wyroby garmażeryjne/ } \\
\text { Ready to eat food (cold) }\end{array}$} & Nie/No & 1,87 & 0,89 & \multirow{2}{*}{0,605} \\
\hline & Tak/Yes & 1,97 & 0,93 & \\
\hline
\end{tabular}

Źródło: opracowanie własne

Source: author's own analysis 
Pracownice oddziałów zabiegowych częściej w pracy spożywały dania typu instant niż pracownice oddziałów zachowawczych. Nie wykazano istotnych różnic w częstotliwości spożycia dań gotowych w pracy w zależności od systemu pracy respondentek.

\section{Dyskusja}

Niniejsza praca stanowi próbę oceny zachowań żywieniowych pielęgniarek w środowisku pracy. Jednym z czynników mogących mieć wpływ na prezentowane przez pielęgniarki zachowania żywieniowe jest system pracy. Praca zmianowa jest utożsamiana z niezdrowymi nawykami żywieniowymi [6-8] oraz łączy się ze wzrostem ryzyka występowania chorób wśród personelu [9]. W badanej grupie dominowały osoby pracujące w systemie równoważnym. Jak podkreśla się w literaturze, praca w godzinach nocnych jest wyczerpująca i stresująca [10]. U osób pracujących w nocy zmienia się rytm okołodobowy.

W czasie nocnego czuwania wzmagają się głód i potrzeba spożycia posiłku [6]. Posiłki nocne są zazwyczaj monotonne, spożywane w pośpiechu, bez zwracania uwagi na okoliczności ich spożycia [11]. Szpital jako miejsce pracy nie gwarantuje zazwyczaj dostępu do korzystnych zdrowotnie posiłków. Analizy własne potwierdzają częstsze spożycie posiłków w porze nocnej w pracy niż w domu. W pracy jest zwykle spożywany posiłek zimny - wskazują na to również wyniki uzyskane przez B. Bilskiego [12]. Zgodnie z zaleceniami nocny posiłek w pracy powinien być pełnowartościowy i ciepły, ze zmniejszoną zawartością węglowodanów, spożyty najpóźniej do godziny pierwszej w nocy. Wpływa on wtedy pozytywnie na funkcjonowanie organizmu, obniża zmęczenie i senność [13]. B. Bilski w swoich badaniach stwierdził, że potrawy typu „fast food” były najczęściej spożywane w porze nocnej przez 10\% pielęgniarek jako posiłek ciepły [12]. Badania własne nie potwierdziły spożywania dań typu „fast food” w porze nocnej, natomiast $11 \%$ pielęgniarek spożywało tego typu dania w pracy kilka razy w miesiącu, a $30 \%$ przynajmniej raz w miesiącu. Blisko połowa badanych nie spożywała w pracy posiłku w porze nocnej-to spostrzeżenie znacznie odbiega od wyników B. Bilskiego, według których nie spożywało nocnego posiłku 17,6\% badanych, a 10\% piło wyłącznie kawę [12]. Respondentki ze stażem pracy > 5-10 lat częściej spożywały posiłki w porze nocnej niż osoby z pozostałych grup wiekowych. Wynikać to może z większego zapotrzebowania energetycznego, charakterystycznego dla grup młodszych wiekiem [14]. Syndrom podjadania w nocy w czasie wolnym od pracy wśród pielęgniarek, stwierdzony w prezentowanym badaniu, wykazały również badania G. Gaweł i wsp.:
19\% osób spożywało posiłek zimny, a 14\% - ciepły [15]. Wyniki badań potwierdzają, że gorsza jakość snu może zwiększać apetyt [6].

Zgodnie z zaleceniami norm żywienia człowieka liczba posiłków spożywanych w ciągu dnia powinna wynosić 4-5 [14]. Z badań J. Bielak i wsp. wynika, że $30 \%$ pielęgniarek spożywa 1-2 posiłki w ciągu dnia, $25 \%$ wychodzi z domu, nie zjadłszy śniadania [16]. W analizach własnych wykazano dwukrotnie większy odsetek spożycia 4-5 mniejszych posiłków w domu niż w pracy. Prawie trzykrotnie częściej były jadane 1-2 duże posiłki w pracy niż w domu.

Zgodnie z literaturą powielane błędy żywieniowe, takie jak: brak czasu, jedzenie w pośpiechu, nieregularność oraz mała częstotliwość spożywanych posiłków, stanowią czynniki ryzyka wystąpienia chorób serca, nadciśnienia, sprzyjają przybieraniu na wadze i w konsekwencji - otyłości [17-19]. W badanej grupie liczba spożywanych w pracy była zależna od stażu pracy, co potwierdziły również wyniki A. Filipczuk i I. Wrońskiej [20]. W badanej grupie liczba posiłków spożywanych przez osoby pracujące w oddziałach zachowawczych była większa niż liczba posiłków spożywanych przez osoby z oddziałów zabiegowych. Może to wynikać z innego tempa i organizacji pracy w tych oddziałach. O istotnych różnicach w odżywianiu pielęgniarek oddziałów zabiegowych i internistycznych napisali również w swojej pracy W.L. Lee i wsp. [21]. Pielęgniarki oddziałów chirurgicznych częściej traktowały odżywianie jako styl promujący zdrowie. W badanej grupie system pracy różnicował liczbę spożywanych posiłków w domu ( $p=0,027)$, regularność spożycia obiadu $(p=0,012)$, podwieczorku $(p=0,005)$ w domu oraz podwieczorku w pracy $(p=0,031)$. Nie miał on natomiast wpływu na regularność spożycia posiłków w pracy. Wyniki badań L. Sochockiej i wsp. wskazują również, że tylko 6 (2,5\%) spośród 245 pracowników ochrony zdrowia spożywa obiad w pracy [18]. W opinii pielęgniarek praca dwuzmianowa przyczynia się do nieregularności odżywiania oraz większego spożycia stymulatorów, takich jak mocna kawa i herbata [22].

Dostępność stołówki/baru nie wpływała na liczbę spożywanych posiłków w pracy w badanej grupie, co może wynikać np. z faktu niemożności wyjścia podczas pracy na obiad, braku uregulowań prawnych w tym względzie, wysokich cen proponowanych posiłków w barze/stołówce. Na zależność stosowanej diety od warunków materialnych wskazało 54,2\% pielęgniarek badanych przez E. Warchoł-Sławińską i wsp. Z badań autorów wynika również, że 25\% pielęgniarek odżywia się nieracjonalnie, natomiast $76 \%$ nie spożywa śniadań przed wyjściem do pracy [23]. Obowiązek zapewnienia przez pracodawce posiłków i napojów pracowniko- 
wi regulują art. 232 Kodeksu pracy [24] oraz przepisy Rozporządzenia Rady Ministrów z dnia 28 maja 1996 r. w sprawie profilaktycznych posiłków i napojów (Dz.U. z 1996 r. Nr 60, poz. 279) [25]. Mówią one, że gorący posiłek lub możliwość spożycia pełnowartościowego posiłku w punktach gastronomicznych przysługuje osobom pracującym w szczególnie uciążliwych warunkach zapisy te nie odnoszą się zatem do pracy pielęgniarek.

Wykazano istotne statystycznie różnice w spożyciu niektórych przekąsek w domu i pracy. Przekąskami rzadziej spożywanymi w pracy niż w domu były: owoce, jogurty/serki, słodycze, chipsy i orzeszki. Warzywa, owoce, soki owocowe i warzywne, orzechy mogą służyć jako przekąski, gdyż uzupełniają zapotrzebowanie organizmu na witaminy i minerały. Zawierają małą ilość cukru, który spożywany w nadmiarze gromadzi się w postaci tkanki tłuszczowej [14]. Wnioski z badań innych autorów [16, 26-28] zdają się potwierdzać wyniki badań własnych na temat nieracjonalnego spożywania słodyczy i przekąsek. Słodycze jako przekąska były spożywane przez 28 (20\%) pielęgniarek codziennie w pracy i 47 (33,6\%) codziennie w domu. Ogółem spożywała je codziennie jedna czwarta badanych. Z badań L. Sochockiej wynika, że 58 (25\%) personelu medycznego uznaje podjadanie między posiłkami za metodę walki ze stresem związanym z sytuacjami trudnymi w środowisku pracy oraz przeciążeniem pracą [18]. Na fakt zwiększonego spożycia niezdrowych przekąsek wśród osób pracujących w systemie zmianowym zwrócono uwagę w pracy G. Heath i wsp. [7]. Wyniki badań własnych nie potwierdziły wskazywanego w literaturze [29] częstszego spożycia słodyczy w pracy w związku z otrzymywaniem ich jako podziękowania od pacjentów lub ich rodzin.

W badanej grupie najczęściej spożywanym produktem spożywczym był nabiał. Nie oznacza to jednak, że jego konsumpcja była na wystarczającym poziomie. Według norm żywienia człowieka dzienne racje powinny zawierać trzy porcje nabiału i jego przetworów [14]. Częstość spożycia tych produktów w pracy była niższa niż w domu. Nabiał był spożywany tylko przez 61 (43\%) badanych codziennie, natomiast przez 56 (40\%) - 3-4 razy w tygodniu. O zbyt niskim spożyciu nabiału wśród personelu medycznego donoszą w swoich pracach również inni autorzy [15, 16, 28, 30]. Analiza badań własnych potwierdziła małą podaż ryb i przetworów rybnych w badanej grupie. Mniej więcej połowa respondentek jadała ryby 1-2 razy tygodniu, jedna trzecia - raz w miesiącu, a pozostałe ankietowane-jeszcze rzadziej. Małe spożycie ryb wśród lekarzy potwierdziły wyniki badań M. Gacek [26], a w grupie pielęgniarek i położnych - wyniki J. Bielak i wsp. [16]. Zgodnie z zasadami prawidłowego żywienia produkty zbożowe pełno- ziarniste (kasze, makarony, pieczywo) powinny stanowić pięć porcji w ciągu dnia [14]. Codzienne spożycie pieczywa razowego deklarowały $44(31,4 \%)$ ankietowane, kasz, makaronów i ryżu-7 (5\%), a ziemniaków-5 (3,6\%). Odniesienie do omawianych wyników badań własnych mogą stanowić przeprowadzone w grupie lekarzy [26] oraz pielęgniarek [16] badania, które potwierdzają, że te produkty są spożywane w niedostatecznej ilości. Badania własne nie potwierdziły wyników J. Bielak wskazujących na zbyt częste spożycie mięsa wśród pielęgniarek. Z badań własnych wynika, że owoce są drugim co do częstotliwości spożycia produktem wskazanym przez respondentki.

W badanej grupie nie ma osoby, która by jadała owoce rzadziej niż raz w tygodniu. Zgodnie z zaleceniami w ciągu dnia powinno się spożywać 3-4 porcje owoców [31], a zatem ich spożycie w badanej grupie należy uznać za niewystarczające. Na fakt niskiego spożycia tej grupy produktów zwrócono również uwagę w wynikach badań słuchaczy medycznego studium zawodowego [30], pielęgniarek i położnych [16] oraz pracowników ochrony zdrowia [18]. Na zbyt małe spożycie surowych warzyw i owoców każdego dnia zwrócili również uwagę inni autorzy [16, 32-34]. Z badań własnych wynika, że spożywane przez pielęgniarki w pracy posiłki to przede wszystkim kanapki oraz gotowe produkty spożywcze typu: posiłki pakowane próżniowo, mrożonki, produkty typu „fast food”, półprodukty, wyroby garmażeryjne, konserwy. Produkty te są ciężkostrawne, kaloryczne i zawierają konserwanty. Wyniki badań przeprowadzonych w Stanach Zjednoczonych wykazały, że 2475 (62\%) pielęgniarek zjada „śmieciowe jedzenie" dwa lub więcej razy w tygodniu [35].

Wyniki badań własnych wskazują, że herbata jest najczęściej wypijanym napojem w pracy. Częste picie herbaty nie jest zalecane, gdyż nie wnosi korzyści pod względem odżywczym (jest napojem odwadniającym) [31]. Woda mineralna jest drugim po herbacie co do częstotliwości wypijania napojem w badanej grupie w pracy. Dorosły człowiek powinien wypijać około 2 litrów wody mineralnej w ciągu dnia. Spożycie wody mineralnej w środowisku medycznym na dość niskim poziomie potwierdzają wyniki badań prowadzonych w grupie lekarzy [26]. Jednym z błędów dietetycznych wpływającym niekorzystnie na organizm wykazanym w badaniach B. Bilskiego jest wypijanie dużych ilości kawy i herbaty w godzinach nocnych, co prowadzi do zwiększenia utraty mikroelementów z organizmu [12] Kawa wypijana jest przez pielęgniarki w pracy z podobną częstotliwością co woda. Kilka razy w ciągu dnia spożywało ją w pracy 53 (38\%) badanych. Nie wykazano, aby system pracy sprzyjał wypijaniu większych ilości kawy w pracy. Niektórzy autorzy potwierdzają w swo- 
ich badaniach nadmierne spożywanie kawy zwłaszcza w porze nocnej w pracy $[12,25]$. Kawa jest istotnie częściej preferowanym napojem w pracy wśród respondentek z dłuższym stażem pracy. Wynikać to może z tego, że spożywana jako ciepły napój powoduje uczucie sytości i traktowana jest alternatywnie jako posiłek. Kawa jest napojem istotnie częściej wypijanym w oddziałach zachowawczych niż zabiegowych. Wyniki te mogą wiązać się z cechami środowiska pracy, jej charakteru i specyfiki. Badane osoby rzadziej piły w pracy niż w domu napoje typu: soki owocowe i warzywne, napoje mleczne, niegazowane i gazowane. System pracy pielęgniarek nie wpływał istotnie na częstość picia napojów w pracy.

Personel medyczny z racji wykonywanej pracy jest zobligowany do promowania zdrowia i aktywizowania społeczeństwa w zakresie preferowania zachowań prozdrowotnych, również w odniesieniu do żywienia. Ma to robić nie tylko poprzez edukację, ale przykład własny. W badaniach A. Filipczuk i I. Wrońskiej wszystkie ankietowane pielęgniarki potwierdziły, że ich postawy i zachowania zdrowotne mogą pozytywnie lub negatywnie wpływać na kształtowanie zachowań zdrowotnych ich podopiecznych [20].

Energia dostarczana wraz z pożywieniem służy do utrzymania na odpowiednim poziomie funkcjonowania organizmu, jego struktury, wzrostu i motoryki [14]. Ilość energii dostarczanej do organizmu powinna być adekwatna do zużywanej, a zatem sposób odżywiania personelu może wpływać na jego efektywność w pracy wymagającej wzmożonej aktywności psychicznej i fizycznej. Pracodawca, mając na uwadze specyfikę pracy personelu pielęgniarskiego, powinien dążyć do tworzenia środowiska pracy promującego zdrowie. Racjonalne wydaje się rozpatrzenie poprawy warunków socjalno-bytowych pielęgniarek pracujących w systemach nocnych [12].

\section{Wnioski}

$\mathrm{Na}$ zachowania żywieniowe pielęgniarek w środowisku pracy nie ma wpływu dostępność do stołówki/baru w miejscu pracy. Pielęgniarki pracujące w oddziałach zachowawczych spożywają większą liczbę posiłków oraz wypijają więcej kawy. Pielęgniarki ze stażem pracy powyżej 10 lat spożywają większą liczbę posiłków w pracy, pielęgniarki ze stażem 6-10 lat spożywają częściej przekąski w pracy.

\section{Piśmiennictwo}

1. Gawęcki J, Mossor-Pietraszewska T (red.). Kompendium wiedzy o żywności, żywieniu i zdrowiu. Warszawa: PWN; 2014.14

2. Jeżewska-Zychowicz M. Zachowania żywieniowe i ich uwarunkowania. Warszawa: Wydawnictwo SGGW; 2007. 7.
3. Jeżewska-Zychowicz M. Zmiana zachowań żywieniowych a profilaktyka zdrowotna. Warszawa: Wydawnictwo SGGW; 2011. 39-41.

4. Woynarowska B. Edukacja zdrowotna. Warszawa: PWN; 2007. 264-266.

5. Karski J. Praktyka i teoria promocji zdrowia. Warszawa: CeDeWu; 2008. 222.

6. Buss J. Associations between obesity and stress and shift work among nurses. Workplace Health Saf. 2012; 60 (10): 453-458.

7. Heath G, Roach GD, Dorrian J, Ferguson SA, Darwent $D$, Sargent $C$. The effect of sleep restriction on snacking behaviour during a week of simulated shiftwork. Accid Anal Prev. 2012; 45: 62-67.

8. Wong $\mathrm{H}$, Wong $\mathrm{M}$, Wong $\mathrm{S}$, Lee A. The association between shift duty and abnormal eating behavior among nurses working in a major hospital: A cross-sectional study. Int $\mathrm{J}$ Nurs Stud. 2010; 47 (8): 1021-1027.

9. Burdelak W, Pepłońska B. Praca w nocy a zdrowie pielęgniarek i położnych - przegląd literatury. Med Pr. 2013; 64 (3): 397-418.

10. Olejniczak D. Praca zmianowa. Mag Pielęg Poł. 2012; (3): 18-19.

11. Zużewicz K, Kwarecki K, Waterhouse J. Skutki fizjologiczne pracy zmianowej i nocnej: poradnik organizatora pracy zmianowej. Warszawa: Centralny Instytut Ochrony Pracy 2001.13-53.

12. Bilski B. Wpływ pracy zmianowej na sposób odżywiania się i patologię przewodu pokarmowego wśród pielęgniarek wyniki badania pilotowego. Med Pr. 2006; 57 (1): 15-19.

13. Indulski JA, Makowiec-Dąbrowska T, Starzyński Z. Wpływ pracy nocnej na stan zdrowia. Med Prakt. 1989; 40 (3): 153-161.

14. Jarosz M, Respondek W, Wolnicka W. Zalecenia dotyczące żywienia i aktywności fizycznej. W: Jarosz M (red.). Normy żywienia dla populacji polskiej - nowelizacja. Warszawa: İ̇iż; 2012. 154-155.

15. Gaweł G, Kin J, Twarduś K, Papała E. Zachowania prozdrowotne pielęgniarek. Piel Położ. 2006; 48 (5): 23-26.

16. Bielak J, Krzyszycha R, Szponar B. Dietary habits of Nurses and midwives from Lublin and its region. Ann UMCS, Sectio D Medicina. 2006; 61 (2): 868-873.

17. Piórecka B, Markielowska A, Schlegel-Zawadzka M. Zwyczaje i wiedza żywieniowa pielęgniarek $z$ województwa małopolskiego. Bromat Chem Toksykol. 2004; 37 supl.: 101-106.

18. Sochocka L, Wojtyłko A, Grad I, Kiliś-Pstrusińska K. Sposób odżywiania pracowników ochrony zdrowia na przykładzie studentów niestacjonarnych PMWSZ w Opolu. Piel Zdr Publ. 2012; 2 (2): 109-112.

19. Zacharewicz K, Kucharska A, Sińska B. Ocena sposobu żywienia osób pracujących w systemie zmianowym. Zdr Publ. 2012; 122 (1): 24-28.

20. Filipczuk A, Wrońska I. Promocja zdrowia wśród pracowników ochrony zdrowia. Ann UMCS. 2003; 58 (supl.), 13, 5: 319-326.

21. Lee WL, Tsai SH, Tsai CW, Lee CY. A study on work stress, stress coping strategies and health promoting lifestyle among district hospital nurses in Taiwan. J Occup Health. 2011; 53 (5): 377-383.

22. Sokołowska B, Borzęcki AJ. Two-shift work versus selected elements of health behavior of nurses. Ann UMCS. 2005; 60, 90: 319-326.

23. Warchoł-Sławińska E, Włoch K. Zachowania zdrowotne pielęgniarek. Zdr Publ. 2003; 113 (1/2): 156-159.

24. Kodeks pracy 2015, art. 232. 
25. Rozporządzenie Rady Ministrów z dnia 28 maja 1996 r. w sprawie profilaktycznych posiłków i napojów. Dz.U. z 1996 r. Nr 60, poz. 279.

26. Gacek M. Zachowania żywieniowe i aktywność fizyczna w grupie lekarzy. Probl Hig Epidemiol. 2006; 92 (2): 254-259.

27. Warchoł-Sławińska E, Włoch K. Zachowania zdrowotne pielęgniarek. Zdr Publ. 2013; 113 (1/2): 156-159.

28. Piórecka B, Markielowska A, Schlegel-Zawadzka M. Sposób żywienia pielęgniarek, a ich przygotowanie do udzielania informacji w zakresie żywności i żywienia. W: Krajewska-Kułak E, Sierakowska M, Lewko J, Łukaszuk C (red.). Pacjent podmiotem troski zespołu terapeutycznego. Białystok: Akademia Medyczna w Białymstoku; 2005. 20-26.

29. Cheung ST. The effects of chocolates given by patients on the well-being of nurses and their support staff. Nutr Health. 2003; 17 (1): 65-9.

30. Cholewa-Zięciak H, Kret M. Ocena sposobu żywienia słuchaczek Medycznego Studium Zawodowego nr 6 w Krakowie. Probl Hig. 2000; 69: 78-82.

31. Jarosz M, Rychlik W. Populacja osób dorosłych. W: Jarosz M (red.). Praktyczny podręcznik dietetyki. Warszawa: Instytut Żywności i Żywienia; 2010. 87.

32. Soll A. Nieregularny tryb pracy a dieta lekarzy, pielęgniarek i ratowników medycznych Wojewódzkiego Centrum Medycznego w Opolu. Wrocław: PAN; 2011.15-17.

33. Ślusarska B, Nowicki G, Piasecka H. Zmiany sposobu żywienia, poziomu aktywności fizycznej oraz wskaźników
BMI, WHR zależne od wieku wśród osób pracujących. Piel XXI w. 2009; 3: 5-10.

34. Zapka JM, Lemon SC, Manger RP, Hale J. Lifestyle behaviors and weight among hospital-based nurses. Nurs Manag. 2009; 17 (7): 853-860.

35. Tucker SJ, Harris MR, Pipe TB, Pipe TB, Stevens SR. Nurses' ratings of their health and professional work environments. AAOHN J. 2010; 58 (6): 253-267.

Artykuł przyjęty do redakcji: 22.10.2015

Artykuł przyjęty do publikacji: 03.12.2015

Źródło finansowania: Praca nie jest finansowana z żadnego źródła. Konflikt interesów: Autorzy deklarują brak konfliktu interesów.

Adres do korespondencji:

Ewa Kobos

ul. Erazma Ciołka 27

01-445 Warszawa

tel.: 228773597

e-mail: kobewa@interia.pl

Zakład Pielęgniarstwa Społecznego

Warszawski Uniwersytet Medyczny 